\title{
ANALISIS PENDAPATAN DAN EFISIENSI USAHATANI KUBIS DI DESA BUKIT ASRI KECAMATAN KAPONTORI KABUPATEN BUTON
}

\author{
Suriadi $^{1)}$, Rabiyatul Jasiyah ${ }^{2)}$, Ni Made Arniase ${ }^{3)}$ \\ Program Studi Agribisnis, Fakultas Pertanian \\ Universitas Muhammadiyah Buton \\ Jl. Betoambari No. 36 Baubau \\ yadisuriadi1969@gmail.com
}

\begin{abstract}
This study aims to (1) determine the income earned by cabbage farmers in Bukit Asri Village, Kapontori Sub-district, Buton Regency (2) Know the efficiency of cabbage farming in Bukit Asri Village, Kapontori Sub-district, Buton Regency. This research was conducted from February 2020 to March 2020 in Bukit Asri Village, Kapontori Sub-district, Buton Regency. The sample in this study were all farmers who worked cabbage totaling 20 people, the determination of the sample was done by census method by taking the whole population from the sample as many as 20 people. The data analysis method used the analysis of production costs, revenue analysis, income analysis, and analysis of the efficiency of the $R C$ farming ratio. The results of this study indicate that cabbage farmers income in Bukit Asri Village, Kapontori Sub-district, Buton Regency with an average reveneue of IDR 11.185.800,- and an average total cost of IDR 3.585.350,- per planting season, so the average income the farmer is IDR 7.600.450,- per planting season. Efficiency of cabbage farming that from the $R C$ ratio results, get an $R C$ ratio of $3,12>1$. This shows that each cost incurred in the amount of IDR 1.000,then gives income of $R p$ 3.120,- with a profit of 2,120,-. It can be concluded that the cabbage farming is profitable and can be developed.
\end{abstract}

Keywords: Farm Efficiency, Cabbage, and Income

\begin{abstract}
Abstrak
Penelitian ini bertujuan untuk (1) Mengetahui pendapatan yang diperoleh petani kubis di Desa Bukit Asri Kecamatan Kapontori Kabupaten Buton, (2) Mengetahui efisiensi usahatani kubis di Desa Bukit Asri Kecamatan Kapontori Kabupaten Buton. Penelitian ini dilakukan pada Bulan Februari 2020 sampai Maret 2020 di Desa Bukit Asri Kecamatan Kapontori Kabupaten Buton. Sampel dalam penelitian ini adalah keseluruhan petani kubis yang berjumlah 20 orang. Penentuan sampel dilakukan dengan metode sensus yaitu dengan mengambil keseluruhan dari populasi sebagai sampel yaitu sebanyak 20 orang. Metode analisis data menggunakan analisis biaya produksi, analisis penerimaan, analisis pendapatan, dan analisis efisiensi usahatani RC ratio. Hasil penelitian ini menunjukkan bahwa pendapatan petani kubis di Desa Bukit Asri Kecamatan Kapontori Kabupaten Buton dengan penerimaan rata-rata sebesar Rp 11.185.800,dan total biaya rata-rata sebesar $\mathrm{Rp} 3.585 .350$,- per musim tanam, jadi pendapatan rata-rata petani adalah sebesar Rp 7.600.450,- per musim tanam. Efisiensi usahatani kubis bahwa dari hasil $\mathrm{RC}$ ratio, memperoleh $\mathrm{RC}$ ratio sebesar 3,12 >1. Hal ini menunjukan bahwa setiap biaya yang dikeluarkan sebesar Rp 1.000,-- maka memberikan penerimaan sebesar Rp 3.120,- dengan
\end{abstract}


keuntungan yang diperoleh sebesar Rp 2.120,-. Dapat disimpulkan bahwa usahatani kubis tersebut menguntungkan dan dapat dikembangkan.

Kata Kunci: Efisiensi, Usahatani, Kubis dan Pendapatan.

\section{PENDAHULUAN}

Tanaman holtikultura mempunyai kedudukan yang sangat penting dalam kehidupan masyarakat, peranannya sebagai sumber gizi. Sedangkan dalam perekonomian mempunyai nilai ekonomis yang tinggi dilihat dari sumber daya terhadap peningkatan Devisa Negara (Patricia, 2001). Komoditas hortikultura yang terdiri dari tanaman buah-buahan, sayuran, tanaman hias dan tanaman obat merupakan komoditas yang sangat prospektif untuk dikembangkan melalui usaha agribisnis, mengingat potensi serapan pasar di dalam negeri dan pasar internasional terus meningkat. Kubis merupakan salah satu sayuran yang termasuk dalam kelompok enam sayur segar yang diekspor Indonesia, yang terdiri dari kol, kentang, tomat, cabai, dan bawang merah.

Besarnya pendapatan yang diterima petani melalui kegiatan usahataninya banyak ditentukan oleh perilaku petani itu sendiri dalam hal jenis cabang usahatani serta mempengaruhi faktor-faktor produksi seefektif dan seefisien mungkin. Selain itu pula, pendapatan petani secara tidak langsung dipengaruhi oleh keadaan iklim, namun juga oleh harga produk yang bersangkutan. Peningkatan pendapatan disektor pertanian perlu mendapat perhatian disebabkan karena pada umumnya penduduk Indonesia hidup dan dihidupkan dari usaha pertanian (Ronny, 2010).

Tabel 1. Data Luas Lahan, Produksi dan Produktivitas Kubis di Kabupaten Buton pada Tahun 2017-2019.

\begin{tabular}{lcccc}
\hline No & Tahun & $\begin{array}{c}\text { Luas lahan } \\
\text { (ha) }\end{array}$ & $\begin{array}{c}\text { Produksi } \\
\text { (ton) }\end{array}$ & $\begin{array}{c}\text { Produktivitas } \\
\text { (ton/ha) }\end{array}$ \\
\hline 1. & 2017 & 20 & 280 & 14 \\
\hline 2. & 2018 & 22 & 330 & 15,20 \\
\hline 3. & 2019 & 25 & 350 & 14 \\
\hline \multicolumn{2}{l}{ Sumber $:$ Buton Dalam Angka }
\end{tabular}

Berdasarkan Tabel 1, dapat dilihat bahwa luas lahan kubis pada tahun 2017 sebesar 20 ha dengan produksi sebesar 280 ton dengan tingkat produktivitas sebesar 14 ton/ha. Pada tahun 2018 mengalami peningkatan luas lahan 22 ha dengan pencapaian produksi sebesar 330 ton dengan tingkat produktivitas 15,20 ton/ha. Pada tahun 2019 juga terjadi peningkatan luas lahan 25 ha dengan pencapaian produksi 350 ton dengan tingkat produktivitas sebesar 14 ton/ha. Untuk meningkatkan produktivitas selain dipengaruhi oleh sumber daya alam, juga dipengaruhi oleh faktor produksi lainnya serta penerapan teknologi yang memadai. Menurut Soekartawi (1998) bahwa hal tersebut disebabkan oleh kurangnya kemampuan petani dalam menerapkan teknologi. Namun demikian perlu diperhatikan aspek efisiensi usahatani sehingga biaya-biaya yang dikeluarkan selama produksi seimbang dengan pendapatan yang diperoleh setelah panen. Karena apabila dalam kegiatan produksi kurang memperhatikan efesiensi usahatani mustahil seorang petani dapat memperoleh hasil yang menguntungkan. Disamping itu kondisi harga yang tidak stabil atau fluktuasi harga merupakan salah satu fenomena pasar yang seringkali harus dihadapi oleh petani sayuran, termasuk didalamnya adalah petani kubis di Desa Bukit Asri, Kecamatan Kapontori. Kondisi fluktuasi harga 
tersebut dapat disebabkan oleh beberapa hal diantaranya adalah produksi yang tidak kontinyu, pengaruh musim yang tidak menentu, adanya bencana alam serta faktor-faktor lainya.

Adanya kondisi fluktuasi harga yang terjadi seperti ini dapat mempengaruhi kondisi pendapatan petani dari usahatani kubis, karena pada saat melakukan kegiatan produksi petani mengeluarkan biaya yang cukup besar. Oleh karena itu, untuk melihat dari adanya fluktuasi harga terutama pada komuditas kubis, perlu adanya suatu analisis terhadap pendapatan petani dari usahatani kubis yang dilakukan, analisis tersebut bertujuan untuk mengetahui sejauh mana kegiatan usahatani kubis memberikan keuntungan untuk petani kubis terutama pada saat harga kubis dipasaran turun atau relatif rendah, apakah tetap mengguntungkan atau tidak bagi petani di Desa Bukit Asri Kecamatan Kapontori.

Berdasrkan latar belakang yang telah diuraikan di atas maka rumusan masalah pada penelitian ini adalah:

1. Seberapa besar pendapatan yang diperoleh petani kubis di Desa Bukit Asri Kecamatan Kapontori Kabupaten Buton?

2. Apakah pendapatan usahatani kubis yang diperoleh petani di Desa Bukit Asri Kecamatan Kapontori Kabupaten Buton sudah efisien?

Tujuan yang ingin dicapai dalam penelitian ini adalah untuk:

1. Mengetahui besar pendapatan yang diperoleh petani kubis di Desa Bukit Asri Kecamatan Kapontori Kabupaten Buton.

2. Mengetahui efisiensi usahatani kubis di Desa Bukit Asri Kecamatan Kapontori Kabupaten Buton

\section{METODE PENELITIAN}

Penelitian ini dilaksanakan pada Bulan Februari sampai dengan Bulan Maret 2020 di Desa Bukit Asri Kecamatan Kapuntori Kabupaten Buton.

Populasi pada penelitian ini adalah keseluruhan petani yang ada di Bukit Asri yang menanam tanaman kubis yang berjumlah 20 orang (Kantor Desa Bukit Asri, 2020). Menurut Arikunto (1998), sampel merupakan sebagian atau keseluruhan dari populasi yang akan diteliti. Sampel penelitian adalah seluruh populasi yang diambil sebagai sumber data serta mewakili keseluruhan dari populasi. Karena popoulasi <100, maka penarikan sampel dilakukan secara sensus dengan mengambil keseluruhan dari populasi sebagai sampel yaitu sebanyak 20 orang. Berdasarkan pendapat Arikunto (1993) bahwa jika subyeknya <100, lebih baik dipakai keseluruhan dari populasi sehingga pengambilan sampel dilakukan secara sensus. Selanjutnya jika subyeknya di atas 100 maka bisa di ambil sampel antara 10-15\% atau 20-25\% ataupun lebih.

Variabel yang diamati dalam penelitian ini adalah:

1) Identitas responden: umur, pendidikan, pengalaman berusahatani, tanggungan keluarga dan luas lahan garapan.

2) Produksi kubis (kg)

3) Harga jual $(\mathrm{Rp} / \mathrm{kg})$

4) Biaya produksi usahatani kubis

$\checkmark$ Biaya tetap yaitu pajak dan penyusutan alat

$\checkmark$ Biaya tidak tetap yaitu biaya bibit, pupuk, pestisida, serta tenaga kerja

Metode yang digunakan dalam analisis data tujuan pertama adalah analisis data deskriptif kuantitatif. Analisis kuantitatif yang digunakan yaitu analisis biaya produksi, analisis penerimaan usahatani dan pendapatan usahatani. Untuk mengetahui besarnya biaya, penerimaan dan pendapatan usahatani maka peneliti mengunakan rumus yaitu sebagai berikut: 
1) Menurut Gilarso (2003), biaya total adalah penjumlahan dari keseluruhan biaya yaitu biaya tetap dan biaya variabel yang dikeluarkan untuk menghasilkan output. Gilarso, (2003) secara matematis biaya produksi dapat ditulis:

$\mathbf{T C}=\mathbf{T F C}+\mathbf{T V C}$

Keterangan:

TC : Total biaya produksi (total cost)

TFC : Total biaya tetap (total Fixed cost)

TVC : Total biaya variabel (total variabel cost)

2) Penerimaan total (total revenue) adalah keseluruhan dari jumlah produksi atau output yang dihasilkan (Q) dan dikalikan dengan harga produksi (P).

Soekartawi (2011), Penerimaan dapat dirumuskan yaitu sebagai berikut:

$\mathbf{T R}=\mathbf{P}$. $\mathbf{Q}$

Keterangan:

TR : Penerimaan total (total revenue)

Q : Jumlah produksi (output)

$\mathrm{P} \quad$ : Harga produksi (price)

3) Pendapatan total yaitu selisih antara penerimaan yang diperoleh dengan keseluruhan biaya yang dikeluarkan dalam usahatani Suratiyah (2009), adapun rumus pendapatan yaitu:

Pd=TR - TC

Keterangan :

$\mathrm{Pd}=$ Total Pendapatan $(\mathrm{Rp})$

$\mathrm{TR}=$ Total Penerimaan $(\mathrm{Rp})$

$\mathrm{TC}=$ Total Biaya $(\mathrm{Rp})$

Metode yang digunakan dalam analisis data pada tujuan kedua adalah analisis data deskriptif kuantitatif. Analisis kuantitatif yang digunakan meliputi analisis efisiensi usahatani. Untuk mengetahui efisiensi usahatani maka digunakan rumus yaitu sebagai berikut:

1) Efisiensi Usahatani, $\mathrm{R} / \mathrm{C}$ ratio yaitu singkatan dari Revenue cost ratio atau disebut juga perbandingan antara total penerimaan (TR) dengan total biaya (TC) Soekartawi (2002), dirumuskan sebagai berikut:

$\mathbf{R} / \mathbf{C}$ ratio $=\frac{\mathbf{T R}}{\mathbf{T C}}$

Keterangan:

$\mathrm{R} / \mathrm{C}$ ratio $=$ Revenue Cost Ratio

$\mathrm{TR}=$ Total Penerimaan $(\mathrm{Rp})$

$\mathrm{TC} \quad=$ Total Biaya $(\mathrm{Rp})$

\section{HASIL DAN PEMBAHASAN}

\section{Karakteristik Responden}

\section{a. Umur}

Tingkat umur responden berpengaruh terhadap kemampuan fisik untuk bekerja dan cara berpikir yang semakin lambat dalam pengambilan keputusan (Firmansyah, 2015). Melihat maraknya sistem informasi dan teknologi dikalangan masyarakat saat ini dapat dikatakan bahwa baik petani muda maupun petani tua memiliki akses yang sama untuk memperolehnya, sehingga memiliki kemudahan yang sama dalam memperoleh informasi. Namun hasil penelitian yang diperoleh dilokasi penelitian menunjukkan bahwa, antara umur responden dan pengalaman usaha memiliki kaitan yang cukup erat. Petani yang umurnya dominan lebih tua 


\section{P-ISSN: 2527-8479 E-ISSN: 2686-2174}

cenderung mempunyai pengalaman usahatani yang lebih lama dan lebih memahami kegiatan budidaya daripada umur yang lebih muda.

Menurut UU No. 13 Tahun 2003 Bab I pasal 1 ayat 2, menyebutkan bahwa tenaga kerja yang masuk umur produktif adalah tenaga kerja yang berumur 15 tahun sampai berumur 64 tahun dan di atas umur 64 dikelompokkan umur tidak produktif. Penyajian tabel keadaan penduduk kubis menurut kelompok umur dapat dilihat pada Tabel 2 berikut.

Tabel 2. Identitas Petani kubis menurut Kelompok Umur di Desa Bukit Asri Kecamatan Kapontori Kabupaten Buton

\begin{tabular}{llll}
\hline No. & $\begin{array}{l}\text { Umur Responden } \\
\text { (Tahun) }\end{array}$ & $\begin{array}{l}\text { Jumlah Responden } \\
(\text { Orang) }\end{array}$ & $\begin{array}{l}\text { Persentase } \\
(\%)\end{array}$ \\
\hline 1. & $<15$ & 0 & 0 \\
\hline 2. & $15-64$ & 20 & 100 \\
\hline 3. & $>64$ & 0 & 0 \\
\hline & Total & 20 & 100 \\
\hline
\end{tabular}

Sumber : Analisis Data Primer

Pada Tabel 2, menunjukkan bahwa usahatani kubis di Desa Bukit Asri yang dikelola oleh petani yang masih dalam usia produktif dengan kekuatan fisik yang tinggi dan cenderung mengikuti perubahan. Hal tersebut dapat dibuktikan dengan hasil penelitian menunjukkan bahwa pada usahatani kubis di Desa Bukit Asri sebanyak 20 orang yakni 100\% dalam usia produktif. Berarti kemampuan fisik dan berpikir petani kubis di Desa Bukit Asri cenderung tinggi. Produktifnya umur petani diharapkan lebih mampu untuk meningkatkan usahataninya terutama kubis di Desa Bukit Asri.

\section{b Pendidikan}

Tingkat pendidikan petani sangat berpengaruh terhadap pemikiran serta sikap petani dalam menanggapi pengetahuan maupun inovasi baru dan penguasaan teknologi modern oleh petani. Tingkat pendidikan petani responden dapat lihat pada Tabel 3.

Tabel 3. Pengelompokkan Tingkat Pendidikan Responden pada Usahatani Kubis di Desa Bukit Asri Kecamatan Kapontori Kabupaten Buton

\begin{tabular}{|c|c|c|}
\hline No. Pendidikan & Jumlah (orang) & Persentase (\%) \\
\hline 1. $\mathrm{SD}$ & 13 & 65 \\
\hline 2. SMP & 5 & 25 \\
\hline SMA & 2 & 10 \\
\hline Jumlah & 20 & 100 \\
\hline
\end{tabular}

Sumber: Analisis Data Primer

Dari Tabel 3, menunjukan bahwa sebagian besar petani responden menempuh pendidikan SD sebanyak 13 orang (65\%), untuk SMP sebanyak 5 orang (25\%), dan untuk SMA sebanyak 2 orang (10\%). Sebagian besar pendidikan petani hanya sampai Sekolah Dasar (SD), maka usahatani yang dijalankan sangat sederhana bahkan cenderung diterapkan secara turun temurun atau kebiasaan masyarakat sekitar. Rendahnya tingkat pendidikan petani juga akan berpengaruh terhadap kemampuan petani dalam mengambil informasi, menerima inovasi baru dan penggunaan teknologi modern yang dapat digunakan untuk menunjang keberhasilan usahatani kubis di Desa Bukit Asri. 


\section{c. Jumlah Tanggungan Keluarga}

Jumlah tanggungan keluarga petani responden yaitu istri, anak, serta tanggungan lainnya. Jumlah tanggungan keluarga adalah banyaknya yang tinggal dalam satu keluarga maka secara langsung akan menjadi tanggungan kepala keluarga ataupun yang ada diluar rumah tetapi hidupnya masih menjadi tanggungan kepala keluarga yang bersangkutan (Soeharjo dan Patong, 1984).

Jumlah tanggungan keluarga yang besar, disamping mempengaruhi kreatifitas dalam mengelola usahataninya, juga akan mempengaruhi pendapatan dan kesejahteraan keluarga petani itu sendiri. Hal ini dimungkinkan terutama bila jumlah tanggungan keluarga tersebut ada pada golongan usia produktif, sehingga akan memungkinkan tersedianya tenaga kerja yang dapat dimanfaatkan pada suatu aktivitas usahatani. Tanggungan keluarga pada usahatani kubis di Desa Bukit Asri dilihat pada tabel 4.

Tabel 4. Jumlah Tanggungan Keluarga Petani di Desa Bukit Asri Kecamatan Kapontori Kabupaten Buton

\begin{tabular}{llcc}
\hline No & Jumlah Tanggungan (Jiwa) & Jumlah Responden (Jiwa) & Persentase (\%) \\
\hline 1. & $2-4$ & 16 & 80 \\
\hline 2. & $5-7$ & 4 & 20 \\
\hline & Total & 20 & 100 \\
\hline
\end{tabular}

Sumber: Analisis Data Primer

Pada Tabel 4, menunjukkan bahwa tanggungan keluarga pada petani di Desa Bukit Asri bervariasi. Petani yang mempunyai tanggungan keluarga antara 2-4 adalah sebanyak 16 jiwa (80\%), sedangkan petani yang mempunyai tanggungan keluarga antara 5-7 adalah sebanyak 4 jiwa $(20 \%)$. Tanggungan keluarga mempunyai peran yang penting dalam kegiatan usahatani, hal ini karena anggota keluarga yang banyak dan sudah memasuki usia produktif dapat membantu melakukan kegiatan usahatani. Dari hasil penelitian bahwa untuk memenuhi kebutuhan hidup keluarga responden tidak hanya menjadikan budidaya kubis sebagai pendapatan pokok, melainkan masih banyak pendapatan yang diperoleh dari sektor pertanian lainya yaitu seperti tomat, daun bawang, sawi, buncis, lombok, hasil kebun, dan lain-lain, serta hasil berternak seperti ternak sapi dan ayam.

\section{d. Pengalaman Berusahatani}

Lama usaha merupakan seberapa lama seseorang mendalami usaha yang telah lakukan. Lamanya usaha yang dimaksud adalah waktu yang telah dihabiskan untuk menekuni suatu usaha. Semakin lama usaha maka semakin baik kualitas usaha tersebut (Firdausiyah, 2018). Pengetahuan pada usahatani adalah suatu faktor yang mempengaruhiproduksi yang dihasilkan pada usahatani di Desa Bukit Asri. Semakin tinggi tingkat pengalaman bertani maka semakin baik pula pola pengelolaannya. Pengalaman berusahatani yang telah dijalani oleh petani merupakan guru besar yang dapat dijadikan pelajaran dan merupakan sumber pengetahuan yang dapat menunjang petani dalam pengambilan keputusan, serta memiliki pengalaman untuk lebih mudah mengatasi berbagai masalah yang timbul dalam kegiatan usahatani di Desa Bukit Asri. Petani di Desa Bukit Asri memiliki pengalaman usahatanidapat dilihat lebih jelasnya pada tabel 5 .

Tabel 5. Pengalaman usahatani petani Responden di Desa Bukit Asri Kecamatan Kapontori Kabupaten buton

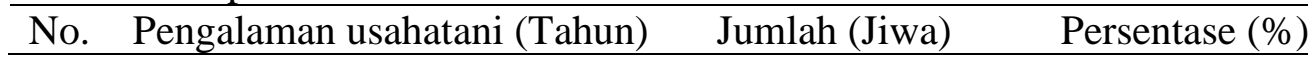




\section{P-ISSN: 2527-8479 E-ISSN: 2686-2174}

\begin{tabular}{llll}
\hline 1. & $<5$ & 2 & 10 \\
\hline 2. & $5-10$ & 15 & 75 \\
\hline 3. & $>10$ & 3 & 15 \\
\hline & Jumlah & 20 & 100 \\
\hline
\end{tabular}

Sumber: Analisis Data Primer

Dari Tabel 5, dapat diketahui bahwa petani kubis di Desa Bukit Asri dominan berpengalaman dalam mnjalankan kegiatan budidaya kubis. Hasil penelitian yang menunjukkan bahwa kategori pengalaman usahatani 5-10 tahun sebanyak 15 orang (75\%), pengalaman $>10$ tahun sebanyak 3 orang $(15 \%)$, dan pengalaman petani yang paling rendah yaitu $<5$ tahun hanya sebanyak 2 orang $(10 \%)$. Petani yang mempunyai pengalaman yang cukup lama bersifat mau berusaha dapat mengelola bididaya yang lebih maksimal.

\section{Karekteristik Usahatani}

\section{a. Luas Lahan Garapan}

Dalam kegiatan usahatani luas lahan garapan adalah suatu input yang sangat penting. Lahan merupakan sumber perekonomian petani di Desa Bukit Asri, maka akan membuat petani untuk berpikir lebih keras lagi bagaimana caranya lahan tersebut dapat memberikan pendapatan yan besar daripada sebelumnya.

Tabel 6. Keadaan Petani Responden Menurut Luas Lahan Garapan di Desa Bukit Asri Kecamatan Kapontori Kabupaten Buton

\begin{tabular}{llcc}
\hline No. & Luas Lahan $(\mathrm{Ha})$ & Jumlah $($ Jiwa) & Persentase $(\%)$ \\
\hline 1. & $0,20-0,25$ & 16 & 80 \\
\hline 2. & $0,26-0,30$ & 4 & 20 \\
\hline & Jumlah & 20 & 100 \\
\hline
\end{tabular}

Sumber: Analisis Data Primer

\section{b. Produksi Usahatani Kubis}

Produksi adalah banyaknya jumlah kubis yang dihasilkan dari usahatani dalam satu musim tanam. Produksi yang dihasilkan oleh petani bervariasi, penyebabnya adanya berbagai macam perbedaan luas lahan, tingkat kesuburan tanah, pemakaian pupuk, dan obat-obatan serta penggunaan jenis bibit. Berikut distribusi responden menurut jumlah produksi kubis yang dihasilkan petani di Desa Bukit Asri Kecamatan Kapontori Kabupaten Buton dapat dilihat pada tabel 7 dibawah ini.

Tabel 7. Jumlah Produksi Kubis Yang Dihasilkan Di Desa Bukit Asri Kecamatan Kapontori Kabupaten Buton

\begin{tabular}{llcl}
\hline No. & Jumlah Produksi $(\mathrm{kg})$ & Jumlah (orang) & Persentase (\%) \\
\hline 1. & $<1.000$ & 1 & $5 \%$ \\
\hline 2. & $1.000-2.000$ & 11 & $55 \%$ \\
\hline 3. & $>2.000$ & 8 & $40 \%$ \\
\hline & Jumlah & 20 & $100 \%$ \\
\hline
\end{tabular}

Sumber: Analisis Data Primer

Pada Tabel 7, diketahui bahwa produksi kubis untuk satu musim tanam dari 20 responden, hanya 1 orang atau $5 \%$ responden yang mampu menghasilkan kubis kurang dari $1.000 \mathrm{~kg}$, sebanyak 11 orang atau $55 \%$ responden yang mampu menghasilkan $1.000-2.000$ $\mathrm{kg}$, kemudian sebanyak 8 orang atau $40 \%$ responden yang mampu menghasilkan kubis lebih 
besar dari $2.000 \mathrm{~kg}$, banyaknya produksi disebabkan oleh berbagai macam faktor yaitu tergantung luas lahan, cuaca, serta perawatannya.

Produksi adalah faktor atau komponen yang sangat menentukan penerimaan suatu usahatani. Produksi yang dimaksud pada penelitian ini yaitu hasil usahatani kubis, maka setiap petani senantiasa berupaya meningkatkan produktivitas usahatani yang diusahakannya sehingga dapat memberikan produk dan pendapatan yang lebih baik. Salah satu keberhasilan usahatani yang dikelola petani kubis adalah jumlah produksi yang peroleh. Produksi kubis di Desa Bukit Asri dengan jumlah rata-rata produksinya yaitu 2.036,8 kg/musim tanam.

\section{c. Biaya Produksi Usahatani Kubis}

Biaya adalah jumlah biaya yang digunakan dalam kegiatan usahatani kubis dalam satu musim tanam. Biaya produksi yaitu berupa biaya tetap (fixed cost) dan biaya tidak tetap (variabel cost).

Biaya variabel yaitu biaya yang dikeluarkan untuk mendapatkan faktor produksi yang dapat diubah jumlahnya atau dapat dikatakan juga sebagai biaya yang dapat berubah dan dapat menentukan besar kecilnya produksi dengan melalui berbagai cara (Bambang dan Kartasapotra, 1992). Adapun Biaya variabel (VC) yang dikeluarkan petani kubis selama produksi kubis dapat dilihat pada tabel 8.

Tabel 8. BiayaVariabel Usahatani Kubis Dalam Satu Musim Tanam di Desa Bukit Asri Kecamatan Kapontori Kabupaten Buton

\begin{tabular}{llrc}
\hline No. & Jenis Biaya & Jumlah Biaya $(\mathrm{Rp})$ & \multicolumn{1}{c}{ Rata-rata Biaya $(\mathrm{Rp})$} \\
\hline 1. & Bibit & 2.100 .000 & 105.000 \\
\hline 2. & Pupuk & 15.525 .000 & 776.250 \\
\hline 3. & Pestisida & 17.305 .000 & 865.250 \\
\hline 4 & Tenaga Kerja & 29.600 .000 & 1.480 .000 \\
\hline & Jumlah & 64.530 .000 & 3.226 .500 \\
\hline
\end{tabular}

Sumber: Analisis Data Primer

Dari Tabel 8, dapat dilihat bahwa selama produksi tanaman kubis, petani mengeluarkan biaya tidak tetap (VC), yaitu biaya rata-rata pengadaan bibit sebanyak Rp 105.000,-, biaya ratarata pengadaan pupuk $\mathrm{Rp} 776.250,-$, biaya rata-rata penggunaan pestisida $\mathrm{Rp} 865.250,-$, ratarata biaya ongkos tenaga kerja $\mathrm{Rp} 1.480 .000,-$. Jumlah tersebut diperoleh dari perhitungan jumlah keseluruhan biaya variabel responden. Semakin tinggi biaya variabel yang digunakan maka produksi yang diperoleh diharapkan semakin tinggi pula.

Biaya tetap adalah biaya yang digunakan tidak berpengaruh terhadap besar kecilnya produksi yang dihasilkan dalam kegiatan produksi. Hasil penelitian ini biaya tetap diperoleh dari penyusutan dengan mengkalikan jumlah pemakaian dan harga satuan yang selanjutnya dibagi dengan umur ekonomis. Hal ini sejalan dengan pendapat Bambang dan Kartasapoetra (1992), bahwa penggolongan biaya kedalam biaya tetap sepenuhnya timbul dari keputusan manajemen misalnya membeli sebuah peralatan dengan memperhitungkan penyusutannya dengan cara tetap (biaya tetap), sehubungan dengan maksud pembelian ini diperhitungkan dengan umur yang panjang. Biaya tetap yang dikeluarkan pada kegiatan produksi kubis dapat diketahui pada tabel 9.

Tabel 9. Biaya Tetap (FC) Usahatani Kubis pada satu musim tanam di Desa Bukit Asri Kecamatan Kapontori Kabupaten Buton

\begin{tabular}{llcc}
\hline No. & Jenis Biaya & Jumlah biay Tetap & Rata-rata biaya \\
\hline 1. & Pajak Bumi dan Bangunan & 246.500 & 12.325 \\
\hline
\end{tabular}


P-ISSN: 2527-8479 E-ISSN: 2686-2174

\begin{tabular}{|c|c|c|c|}
\hline 2. & Penyusutan alat & 6.930 .500 & 346.525 \\
\hline & Jumlah & 7.177 .000 & 358.850 \\
\hline
\end{tabular}

Pada Tabel 9, dapat dilihat bahwa penggunaan biaya tetap selama satu musim tanam yaitu biaya PBB sebesar Rp 246.500,- dengan rata-rata biaya $\mathrm{Rp} 12.325,-$, dan biaya penyusutan alat sebesar Rp 6.930.500,-, dengan rata-rata biaya penyusutan alat sebesar Rp $346.525,-$, jadi jumlah biaya tetap (FC) sebesar Rp 7.177.000,-, dan rata-rata biaya tetap Rp $358.850,-$. Penggunaan total penyusutan tersebut berupa penyusutan alat seperti penyusutan cangkul, penyusutan ember, penyusutan selang, penyusutan tangki semprot, penyusutan terpal, penyusutan pipa, penyusutan gembor dan penyusutan pompa air. Perhitungan biaya penyusutan dengan menggunakan metode garis lurus (Suratiyah, 2011), yaitu dihitung dari nilai ekonomis (nilai awal pembelian dikurangi nilai sisa, diasumsikan nilai sisa nol) alat dibagi dengan umur ekonomis alat (alat yang dapat digunakan).

Total biaya adalah keseluruhan biaya yang digunakan untuk aktivitas produksi dalam satu musim tanam. Biaya total merupakan keseluruhan biaya yang dipakai untuk produksi atau biaya tetap adalah penjumlahan biaya tetap dan biaya variabel. Penggunaan seluruh biaya dalam usahatani kubis dalam satu musim tanam dapat dilihat pada tabel 10 .

Tabel 10. Total Biaya (TC) Usahatani Kubis Dalam Satu Musim Tanam di Desa Bukit Asri Kecamatan Kapontori Kabupaten Buton

\begin{tabular}{llll}
\hline $\begin{array}{l}\text { Luas Lahan } \\
\text { (ha) }\end{array}$ & $\begin{array}{l}\text { Biaya Tetap } \\
(\mathrm{Rp} / \text { produksi })\end{array}$ & $\begin{array}{l}\text { Biaya Variabel } \\
\text { (Rp/produksi) }\end{array}$ & $\begin{array}{l}\text { Total Biaya } \\
\text { (Rp/produksi) }\end{array}$ \\
\hline 4,85 & 7.177 .000 & 64.530 .000 & 71.707 .000 \\
\hline Rata-rata & 358.850 & 3.226 .500 & 3.585 .350 \\
\hline
\end{tabular}

Sumber: Analisis Data Primer

Pada Tabel 10, menunjukkan total biaya yang harus digunakan oleh petani untuk budidaya tanaman kubis dalam satu musim tanam adalah dengan total biaya Rp 71.707.000,-, dan rata-rata biaya $R p 3.585 .350$,-. Untuk menghasilkan pada luas lahan 4,85 ha dalam satu musim tanam, petani harus mengeluarkan biaya tetap sebanyak Rp 7.177.000,-, dan rata-rata biaya $R p$ 358.850,-, dan biaya variabel sebanyak $R p$ 64.530.000,- dan rata-rata biaya $R p$ 3.226.500,-.

\section{d. Harga Jual Kubis}

Harga jual kubis merupakan nilai produk kubis yang berlaku dalam satuan rupiah per kilogram. Harga jual kubis ini berfluktuatif setiap waktu berkisar antara $\mathrm{Rp} 4.000 / \mathrm{kg}-\mathrm{Rp}$ 7.000/kg. Harga jual produksi kubis tinggi ketika produksi kubis sedikit, namun sebaliknya jika produksi banyak maka harga jual kubis menurun. Adanya kondisi fluktuasi seperti ini dapat mempengaruhi kondisi pendapatan petani kubis, sebab dalam melakukan kegiatan produksi petani mengeluarkan biaya yang maksimum. Menurut hasil wawancara langsung dengan responden, diperoleh bahwa rata-rata harga jual kubis di Desa Bukit Asri ialah Rp 5.650/kg.

\section{e. Penerimaan Usahatani Kubis}

Tujuan utama diadakannya usahatani adalah untuk memperoleh hasil berupa penerimaan dari jerih payah petani. Menurut Soekartawi (2016), bahwa penerimaan usahatani adalah banyaknya produksi yang dihasilkan dikalikan dengan harga jual. Penerimaan yang diperoleh 


\section{P-ISSN: 2527-8479 E-ISSN: 2686-2174}

petani pada penelitian ini yaitu sejumlah uang tunai yang diterima petani dari hasil penjualan kubis permusim tanam. Penerimaan usahatani kubis dapat diketahui pada tabel 11.

Tabel 11. Penerimaan Usahatani Kubis dalam satu musim tanam di Desa Bukit Asri Kecamatan Kapontori Kabupaten Buton Tahun

\begin{tabular}{llll}
\hline Uraian & $\begin{array}{l}\text { Jumlah produksi kubis } \\
(\mathrm{kg})\end{array}$ & $\begin{array}{l}\text { Harga produksi } \\
\text { kubis }(\mathrm{kg})\end{array}$ & $\begin{array}{l}\text { Total Penerimaan } \\
(\mathrm{Rp})\end{array}$ \\
\hline Jumlah & 40.736 & 5.650 & 223.716 .000 \\
\hline Rata-rata & $2.036,8$ & 5.650 & 11.185 .800 \\
\hline Sumber: Analisis Data Primer & &
\end{tabular}

Dari Tabel 11, diketahui bahwa jumlah produksi kubis dalam satu musim tanam yaitu sebanyak $40.736 \mathrm{~kg}$ dengan rata-rata harga kubis $\mathrm{Rp} 5.650,-/ \mathrm{kg}$. Maka total penerimaan usahatani kubis dalam satu musim tanam yaitu sebesar Rp 223.716.000,-, dengan rata-rata penerimaan sebesar Rp11.185.800,-.

\section{f. Analisis Pendapatan Usahatani Kubis}

Agar dapat memahami seberapa besar perndapatan yang diterima petani dalam usahatani kubis yang dikelolannya perlu dilakukan analisis pendapatan. Pendapatan pada penelitian ini merupakan selisih dari total penerimaan terhadap produksi kubis dengan jumlah biaya/uang keseluruhan yang digunakan oleh petani dalam usahatani. Berdasarkan hal diatas maka jumlah pendapatan rata-rata petani kubis dalam satu musim panen di Desa Bukit Asri Kecamatan Kapontori Kabupaten Buton terdapat pada tabel 12.

Tabel 12. Rata-Rata Pendapatan Usahatani Kubis di Desa Bukit Asri Kecamatan Kapontori Kabupaten Buton

\begin{tabular}{llcl}
\hline No. & Uraian & Rata-rata & \\
\hline 1. & - Produksi Kubis (kg) & $2.036,8$ & \\
& - Harga jual (Rp) & 5.650 & \\
& Penerimaan rata-rata (Rp) & & Rp 11.185.800 \\
& & & \\
2. & Biaya Produksi & & \\
& - Biaya Tetap (Rp) & 358.850 & \\
& - Biaya Variabel (Rp) & 3.226 .500 & \\
& Biaya rata-rata (Rp) & & $\mathbf{R p ~} \mathbf{3 . 5 8 5 . 3 5 0}-$ \\
3. $\quad$ Rata-rata Pendapatan $(\mathbf{R p})$ & & $\mathbf{R p ~} \mathbf{7 . 6 0 0 . 4 5 0}$ \\
\hline
\end{tabular}

Sumber: Analisis Data Primer

Dari Tabel 12, diketahui bahwa jumlah rata-rata penerimaan petani kubis ialah sebanyak Rp 11.185.800,-, sedangkan jumlah rata-rata biaya yang digunakan sebanyak $\mathrm{Rp}$ 3.585.350,-Jadi jumlah rata-rata pendapatan yang didapatkan petani kubis dalam satu musim tanam ialah sebesar Rp 7.600.450,-.

\section{g. Analisis Efisiensi Usahatani Kubis}

Suatu usahatani bisa dikatakan layak atau untung jika pendapatan yang dihasilkan dari penjualan lebih besar dari pada biaya-biaya produksi yang digunakan. Efisiensi usahatani sangat diperlukan untuk keberlangsungan usahatani kubis di Desa Bukit Asri, penggunaan 
biaya-biaya pada saat produksi harus efisien agar biaya yang dikeluarkan tidak terbuang siasia. Menurut Tasman dan Aima (2018), petani adalah sebagai perusahaan murni yang tujuan utamanya adalah memaksimumkan keuntungan. Efisiensi usahatani dilakukan dengan menganalisis kelayakan usaha yaitu membandingkan antara jumlah penerimaan dengan jumlah keseluruhan biaya atau RC ratio. Perhitungan efisiensi usahatani kubis ( $\mathrm{RC}$ ratio) terdapat pada tabel 13 berikut.

Tabel 13. Efisiensi Usahatani Kubis (R/C ratio) di Desa Bukit Asri Kecamatan Kapontori Kabupaten Buton

\begin{tabular}{lll}
\hline No. & Uraian & Jumlah \\
\hline 1. & Penerimaan Total (Rp) & Rp 223.716.000 \\
2. & Biaya Total (Rp) & Rp 71.707.000 \\
\hline & RC ratio & 3,12 \\
\hline
\end{tabular}

Sumber: Analisis Data Primer

Dari Tabel 13, dapat diketahui bahwa nilai RC ratio usahatani kubis sebesar 3,12 atau lebih besar dari 1 yang berarti setiap Rp 1.000 yang dikeluarkan oleh petani kubis, petani mendapatkan penerimaan sebanyak Rp 3.120 dengan keuntungan yang diperoleh sebesar Rp 2.120.Demikian dapat diartikan bahwa usahatani kubis di Desa Bukit Asri Kecamatan Kapontori Kabupaten Buton efisien dan dapat diteruskan serta memberikan keuntungan untuk para petani karena $\mathrm{R} / \mathrm{C}>1$.

Analisis $\mathrm{R} / \mathrm{C}$ ratio dalam penelitian yang dipakai untuk mengetahui apakah usahatani kubis yang dikembangkan atau diteruskan oleh petani di Desa Bukit Asri Kecamatan Kapontori efisien dan layak di usahakan. Hal ini dikarenakan sebagian besar petani mengaku jika harga rendah maka mereka tidak mendapatkan keuntungan. Namun hal itu tidaklah benar karena dari hasil penelitian ini, dimana peneliti melakukan penelitian disaat harga kubis di pasar relatif rendah dan mengalami fluktuasi menunjukkan bahwa usahatani Kubis tetap menguntungkan bagi petani. Hasil penelitian ini menunjukkan bahwa rata-rata pendapatan petani kubis yaitu sebesar Rp 7.600.450,- dengan RC ratio 3,12.

\section{KESIMPULAN DAN SARAN}

\section{Kesimpulan}

Dari hasil dan pembahasan penelitian yang dilaksanakan di Desa Bukit Asri Kecamatan Kapontori Kabupaten Buton maka disimpulkan bahwa:

1. Pendapatan yang diperoleh petani kubis di Desa Bukit Asri Kecamatan Kapontori Kabupaten Buton yaitu berkisar dari Rp 2.917.000 - 13.364.500,- dengan rata-rata pendapatan sebesar Rp 7.600.450,-.

2. Usahatani kubis di Desa Bukit Asri Kecamatan Kapontori Kabupaten Buton dikatakan efisien, dengan nilai RC ratio usahatani kubis sebesar 3,12 atau lebih besar dari 1 yang berarti setiap pengeluaran biaya sebesar Rp 1.000 untuk produksi kubis memperoleh penerimaan sebesar Rp 3.120 dengan keuntungan yang diperoleh sebesar Rp 2.120.

\section{Saran}

Dari hasil penelitian, peneliti menyampaikan beberapa saran yaitu sebagai berikut:

1. Agar memperoleh hasil yang lebih berkualitas maka memerlukan peran serta dari semua pihak, baik dari pemerintah maupun dari instansi dibidang pertanian untuk membantu 
petani dalam pemberian penyuluhan tentang bagaimana bercocok tanam kubis yang baik sehinga para petani dapat meningkatkan produksinya baik dari segi kualitas ataupun kuantitas.

2. Desa Bukit Asri Kecamatan Kapontori Kabupaten Buton mempunyai kondisi lahan tegalan yang berada dipegunungan, dengan kondisi itu sebaiknya petani melakukan pembenahan tanah dengan memberikan pupuk organik yang lebih banyak daripada pupuk kimia. Penggunaan pupuk organik diharapkan dapat membantu meningkatkan dan menjaga kesuburan tanah, sehingga dapat menimgkatkan produksi kubis. Serta pemakaian bahan kimia yang digunakan dalam pengendalian penyakit dan hama harusnya dilakukan sebaik mungkin agar tidak memberikan dampak negatif pada manusia serta lingkungan.

\section{DAFTAR PUSTAKA}

Badan Pusat Statistik, 2019. Kabupaten Buton Dalam Angka 2017-2019. Badan Pusat Statistik Buton.

Balai Penelitian Sayuran (Balitsa, 2007) Teknik Budidaya Sayuran. Jakarta.

Bambang dan Kartasapoetra, 1912. Kalkulasi dan Pengendalian Biaya Produksi. Jakarta.

Beatle dan Tailor, 1994. Ekonomi dan Produksi. Yogyakarta. Gajah Mada University Press.

Daniel, Moehar, 2002. Pengantar Ilmu Ekonomi Pertanian. Jakarta. Bina Aksara.

Direktorat Bina Perlindungan Tanaman. 1994. Pengelolaan Organisme Penggganggu

Tumbuhan Secara Terpadu Tanaman Kubis. Jakarta. Direktorat Jendaral Tanaman Pangan.

Direktorat Perlindungan Hortikultura, 2005. Kebijakan Teknis Pengendalian OPT. Dalam Makalah Apresiasi Penerapan Penerapan Penenggulanagan OPT Kubis. Surabaya.

Falianty TA, 2019. Teori Ekonomi Makro dan Penerapannya di Indonesia. Depok. PT RAJAGRAFINDO PERSADA.

Gilarso, T. 2003. Analisis Pendapatan UsahataniPada Produk Pertanian. Jakarta; Salemba Empat.

Gustiyana, H. 2003. Analisis Pendapatan Usahatani Untuk Produk Pertanian. Jakarata; Salemba Empat.

Hernanto, F. 2007. Ilmu Usahatani, Penebar Swadaya. Jakarta.

Nasir, 1993. Metodologi Penelitian. Jakarta; PT Rosda Karya.

Pracaya, Ir. 2001. Kola tau Kubis. Jakarta; Penebar Swadaya. Jakarta.

Rahim dan Hastuti, 2002. Ekonomi Pertanian. Jakarta; Penebar Swadaya.

Rintongga, dkk. 2004. Ekonomi I. Jakarta; Erlangga

Rukmana, Rahmat, 1994. Bertanam Kubis. Penerbit Kanisius. Yogyakarta.

Samuelson Paul A, dan Nordhaus, William D, 2003. Ilmu Ekonomi Edisi Bahasa Indonesia, PT Media Global Edukasi. Jakarta.

Semangun H, 2000. Penyakit Penting Tanaman Hortikultura di Indonesia. Edisi Keempat. Yogyakarta. Gaja Mada university Press.

Siregar, Nining M, 2011. Analisis Pendapatan Usahatani dan Faktor yang Mempengaruhi Produk Cabai Merah Keriting di Desa Citapen Kecamatan Ciawi Kabupaten Bogor (Skripsi) Institut Pertanian Bogor.

Soekartawi, 1990. Teori Ekonomi Produksi (Teori dan aplikasi). Raja Grafindo Persada. Jakarta.

Soehardjo dan Patong, D, 1984. Sendi-Sendi Pokk Ilmu Usahatani. Makassar (ID); Universitas Hasanuddin 


\section{P-ISSN: 2527-8479 E-ISSN: 2686-2174}

Sugiarto, dkk. 2007.Ekonomi Mikro Sebuah Kajian Komprenhensif. PT Gramensi Pustaka Utama. Jakarta.

Sugiyono,(2015). Metode Penelitian Pendidikan (Pendekatan Kuantitatif, Kualitatif dan R\&D). Bandung; Alfabeta.

Shinta, A. 2011. Ilmu Usahatani. Universitas Brawijaya Press. Malang.

Sumadji, P.Y, 2006. Kamus Ekonomi, Edisi Pertama. Jakarta; Wacana Intelektual. 